\title{
Analysis of electricity generation in domestic photovoltaic systems, from the perspective of energy cost savings
}

\section{Análisis de generación eléctrica en sistemas fotovoltaicos domésticos, desde la perspectiva de ahorro del costo energético}

\author{
ÁlVAREZ-TORRES, Norma Angélica†*, ROMO-GARCÍA, Verónica Alida, PRADO-MARTíNEZ, \\ Paulina Violeta and CORONADO-PALOMARES, Juan Luis
}

Universidad Tecnológica de Nogales, Sonora. Avenida Universidad \#271, CP. 84000; Nogales, Sonora.

ID $1^{\text {st }}$ Author: Norma Angélica Álvarez Torres / ORC ID: 0000-0002-7075-0945, Researcher ID Thomson: F-2959-2018, CVU CONACYT ID: 897854

ID $1^{\text {st }}$ Co-author: Verónica Alida Romo García / ORC ID: 0000-0002-0516-2362, Researcher ID Thomson: I-5542-2018, CVU CONACYT ID: 905055

ID $2^{\text {nd }}$ Co-author: Paulina Violeta Prado-Martinez / ORC ID: 0000-0002-1302-0129, Researcher ID Thomson: G-13722018, CVU CONACYT ID: 295872

ID $3^{\text {rd }}$ Co-author: Juan Luis, Coronado-Palomares / ORC ID: 0000-0002-0840-3336

DOI: $10.35429 /$ JOTI.2021.15.5.16.21

Received January 12, 2021; Accepted June 24, 2021

\begin{abstract}
Currently, it is increasingly common to find distributed generation systems in Mexico, especially in places where the cost of electricity becomes high, such as in cities with extreme temperatures that require air conditioning systems throughout the year. The present work aims to analyze four photovoltaic solar systems for domestic use, to determine if there is an economic benefit as a result, in the city of Nogales, Sonora. For which it was necessary to interpret the data of the payment receipt, visit the locations to obtain the installation characteristics and make a comparison between the monitored data and the calculated one. One of the outstanding results was that the difference in inclination angle in a range of \pm 10 degrees basically did not affect the efficiency of the systems. In addition to a case with a high energy cost, due that the consumption is greater than the generation of the SSFV. This work contributes with important information to the community, so that better decisions can be made regarding how to reduce the cost of energy used in homes, as it can be approached from the point of view of installing an SSFV and awareness of energy use.
\end{abstract}

SSFV, Interconection, DAC

\begin{abstract}
Resumen
Actualmente, es cada vez más frecuente encontrar sistemas de generación distribuida en México, sobre todo en lugares en los que el costo de la energía eléctrica se vuelve alto, como en ciudades con temperaturas extremas que requieren sistemas de climatización durante todo el año. El presente trabajo tiene como objetivo analizar cuatro sistemas solares fotovoltaicos de uso doméstico, para determinar si existe un beneficio económico como resultado, en la ciudad de Nogales, Sonora. Para lo que fue necesario interpretar los datos del recibo de pago, visitar los domicilios para obtener las características de instalación y realizar una comparación entre los datos monitoreados y los calculados. Uno de los resultados destacados fue que la diferencia en el ángulo de inclinación en un rango de \pm 10 grados, básicamente no afectó la eficiencia de los sistemas. Además de un caso en el costo energético continúa siendo elevado, debido a que el consumo es mayor a la generación del SSFV. Este trabajo contribuye con información importante a la comunidad, de tal forma que se puedan tomar mejores decisiones en cuanto a la forma de reducir el costo por energía utilizado en los hogares, pues se puede abordar desde el punto de vista de instalación de un SSFV y la concientización del uso de la energía.
\end{abstract}

SSFV, Interconexión, DAC

Citation: ÁLVAREZ-TORRES, Norma Angélica, ROMO-GARCÍA, Verónica Alida, PRADO-MARTÍNEZ, Paulina Violeta and CORONADO-PALOMARES, Juan Luis. Analysis of electricity generation in domestic photovoltaic systems, from the perspective of energy cost savings. Journal of Technical Invention. 2021. 5-15: 16-21

\footnotetext{
* Author Correspondence (e-mail: naat80@ hotmail.com)

$\uparrow$ Researcher contributing as first author.
} 


\section{Introduction}

Mexico has a great diversity of climates that can be generally classified according to their temperature in warm and temperate or with respect to humidity, in humid, sub-humid and very dry, however, with the technological advances that have occurred and the development of new measurement techniques and knowledge about the climate, it has become evident that the climatic conditions of the country are dynamic and not static, have shown that the climatic conditions of the country are dynamic and not static, which impacts on the calculation of electricity rates, since these are set according to the climate of the region in addition to the conditions of consumption of users, resulting in different electricity costs within the Mexican Republic. (Tecnológico Nacional de México, 2020).

The Federal Electricity Commission (CFE), which is in charge of charging for electricity consumption, bases the nature of domestic tariffs, their regulation and applicable fees according to a tariff scheme classified as domestic divided into: 1, 1A, 1B, 1C, 1D, 1E and $1 \mathrm{~F}$, as well as high consumption domestic (DAC). (CFE, 2021).

The CFE determines the cost per kilowatt-hour $(\mathrm{kW} / \mathrm{h})$ for each of the regions into which the country is divided by obtaining the average annual temperature of the regions and assigning it to each of the classifications accordingly.

The municipality of Nogales, Sonora, is considered a mountainous territory with a semidry temperate climate (García, 2004). According to $\mathrm{CFE}$, it is classified in tariff $1 \mathrm{~A}$, because according to the calculations made by the company, the average annual temperature is $25^{\circ} \mathrm{C}$, considering it a place with a temperate climate. This does not reflect the reality of the region, because according to historical temperature data (from 1999), it has been recorded that in winter the temperature can approach $-10^{\circ} \mathrm{C}$ and in summer it can reach $44^{\circ} \mathrm{C}$ (Figure 1). (Wheather, 2021),

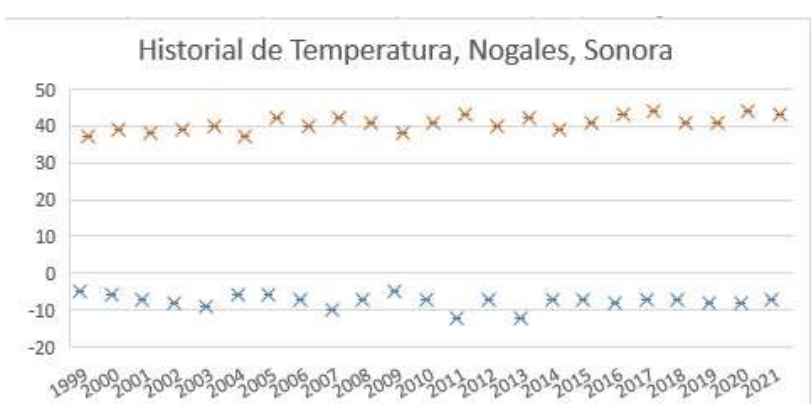

- TEMPERATURA BAIA

Figure 1 Historical Temperature in Nogales, Sonora Source: Own Elaboration with data from Wheather Spark, Historical data in Nogales, Mexico 2021

The above shows the extreme temperatures in the city, which is why citizens need to make use of air conditioning systems in both summer and winter.

Figure 2 shows the cost of energy in summer, and Figure 3 in winter, for tariff $1 \mathrm{~A}$.

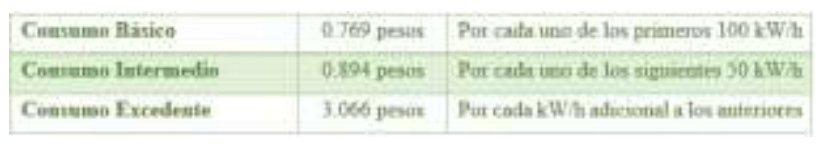

Figure 2 Cost of energy in summer for tariff $1 \mathrm{~A}$ Source: Own elaboration with CFE data

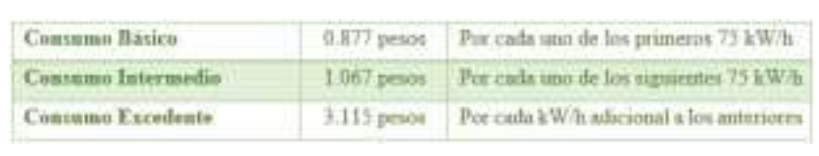

Figure 3 Cost of energy in winter for tariff $1 \mathrm{~A}$ Source: Own Elaboration with CFE data

As can be seen, in winter the cost per $\mathrm{kW} / \mathrm{h}$ is higher, in addition to the fact that the amount of energy that can be used in the different CFE schemes is lower, so users can easily reach the DAC classification, where the cost of energy use increases up to $400 \%$ with the continuous use of electric space heating devices.

To remedy this problem and avoid falling into the DAC rate, some households have opted for the use of fossil energy sources such as gas or firewood for home air conditioning, however, it has been shown that these are not healthy, and can generate adverse effects on the environment; in addition, there have been cases of poisoning and fires in homes. 
According to data from the Mexican Solar Energy Association (ASOLMEX), Mexico has an average solar irradiation of $6.36 \mathrm{kWh} / \mathrm{m} 2$, with a potential to install more than $1800 \mathrm{GW}$, distributed throughout the country, equivalent to 28 times the total installed capacity of the National Electric System (Solar, 2020). Therefore, in the region there has been an increase in investment in the installation of solar photovoltaic systems interconnected to the CFE grid (SSFV) for domestic or small-scale use, as an option to stay in Tariff 1A or leave the DAC Tariff, generating a demand and also an increase in companies dedicated to the sale of such systems, which have different installation techniques.

This generates the need, on the part of the Universidad Tecnológica de Nogales (UTN) and the Academic Body Centro de Aplicación Tecnológica en Mantenimiento y Mecatrónica (CEATEMM), to carry out a preliminary study of the basic factors that can influence the performance of these systems, in order to make it known to society; In addition to raise awareness by this means to the user who has a SSFV, to carry out an efficient use of energy, so that their consumption is not increasing, and is considered the idea that the system will generate unlimited energy needed, or that will support an increased load in the home.

Based on the above, this project proposes the study of four homes with PVSS interconnected to the CFE network, to determine the possible cost-benefit obtained with such installation, considering the angle of inclination, orientation of the system, as well as the generation of energy with respect to the consumption of the home. The objective of this study is to analyze the generation and billing data of PVSS installed in private homes in the city of Nogales, Sonora, in order to determine the existence of an economic benefit in households.

\section{Methodology to be developed}

In order to carry out this work, four domestic PVSS, interconnected to the CFE network, in the city of Nogales, Sonora, were taken into account. The analysis contemplated the physical installation, i.e., the angle of inclination, orientation, location of the house and some other factors that could affect the efficiency of the system (dust, dirt, etc.).
The indicator for measuring performance was the energy generation, taken from the monitoring of the individual systems for one year, it should be noted that all were installed by different companies and for case 3 , there is no monitoring system, so it only reflects the difference between generation and consumption, since it is not possible to measure the actual generation of the system. Once these data were available, a comparison was made to determine the difference in generation and efficiency of the systems.

The development of the article is described below:

\section{Study of the CFE bill with interconnection.}

Four homes with photovoltaic installations interconnected to the CFE network were considered, which were distributed in the city of Nogales, Sonora and their installed capacity was equivalent to each other (approximately 3 $\mathrm{kW} / \mathrm{h})$.

The CFE bills were analyzed in order to determine the tariff in which they were classified and to determine the energy consumed from the network, which is shown in the meter as reading 1.8.0, as well as the $\mathrm{kW}$ that were injected into the network from the system; in this case, the meter shows it in its digital reading 2.8.0. This is identified as the energy that was generated and was not consumed at that time, so it was injected into the CFE grid.

Figure 4 shows an electricity consumption receipt of one of the case studies, in which the mentioned readings can be found, on the other hand, it is also possible to locate information on the energy stored in favor in that period, and if it was possible to store more. 


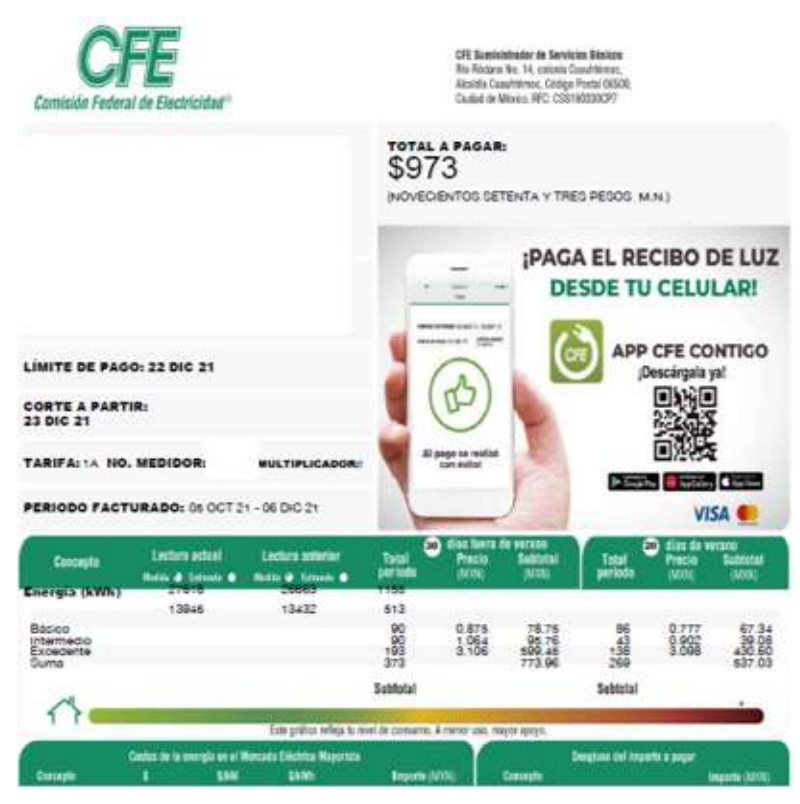

Figure 4 Electricity consumption receipt Source: own elaboration with CFE data, 2021

\section{Tour of the locations of the solar photovoltaic installations.}

After the analysis of the receipts, a visit was made to the homes, which are distributed according to the image shown in Figure 5, where the inclination and orientation of the installation of the solar photovoltaic modules were noted.

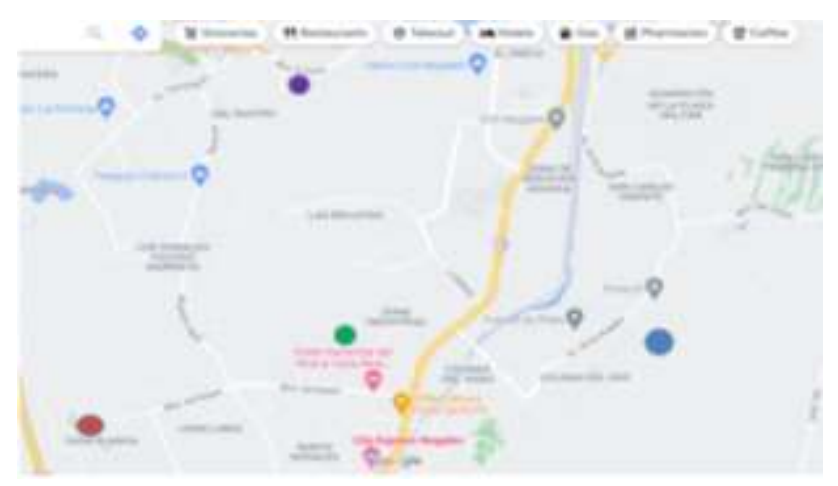

Figure 5 Residential locations of photovoltaic systems under study

Source: own elaboration with data from Google Maps, 2021

\section{Analysis of the monitoring system of the photovoltaic generator and the CFE meter}

In order to analyze the efficiency of the system, it was necessary to know the effective solar radiation time, according to the location of the homes, to achieve this, the National Aeronautics and Space Administration (NASA) page was consulted (VIEWER, 2021), where the locations were selected on the map and the information for different types of solar systems was consulted.
Those that are installed with the inclination were chosen, according to the latitude of the home, as shown in Figure 6.

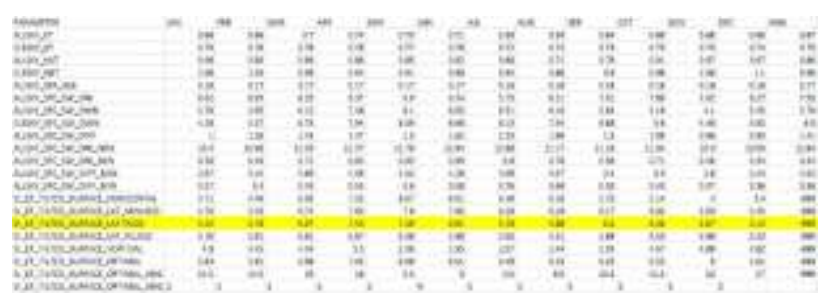

Figure 6 Effective hours of annual solar radiation Source: Prepared by the authors with data from Prediction Of Worldwide Energy Resource, 2021

Once the hours of effective radiation per home were obtained for each month of the year, a spreadsheet was generated (Figure 7), through which the analysis and elaboration of the graphs corresponding to the generation of the systems was carried out, using equation 1 , to obtain the expected amount of electricity for each system:

$$
\mathrm{GC}=(\mathrm{CI}) *(\mathrm{HRE}) *(\text { days/month })
$$

Where:

$\mathrm{GC}=$ Calculated Generation $(\mathrm{Kw} / \mathrm{hr} / \mathrm{month})$

$\mathrm{CI}=$ Installed Capacity $(\mathrm{Kw})$

HRE $=$ Hours of Effective Radiation (hr) days/month $=$ Days contained in the month

\begin{tabular}{|c|c|c|c|c|c|}
\hline \multirow{3}{*}{ MAES } & \multirow{3}{*}{$\begin{array}{l}\text { Heras de } \\
\text { Rediacion } \\
\text { ffectivg }\end{array}$} & \multicolumn{4}{|c|}{ EEIERTCOU CAICUVDA } \\
\hline & & dhate & 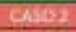 & 2003 & CAso 4 \\
\hline & & $\mathrm{nin}$ & awh & nell & $\mathrm{m}$ \\
\hline ENERO & 5.42 & 0 & 655.278 & 497.3992 & 514.1412 \\
\hline FEAREDO & 5.70 & 427.2576 & 611.178 & 4790964 & 495.2304 \\
\hline MAQ20 & 6.97 & 570.4248 & 842673 & 639.5672 & 161.1742 \\
\hline ASPR & 7.45 & 556.04 & B7LES & 661.56 & 683.91 \\
\hline MANO & 7.29 & 5966136 & 831.362 & 658.9304 & 6913294 \\
\hline JUNIO & 69 & 506.49 & 800.3 & 61272 & 633.42 \\
\hline 2010 & 5.78 & 473.0352 & 698302 & 530.3728 & 548.2506 \\
\hline AGO5TOO & 5.88 & 4812192 & 380.992 & 53954488 & 357.7768 \\
\hline SEPTIEMQRE & 6.2 & 495.04 & 725,4 & 855.6 & 569.16 \\
\hline OctuBase & 6.46 & $52 k 6064$ & 755.22 & 921196 & 6127966 \\
\hline NOVEMBAE & 5.97 & 472.824 & 698.49 & 623.86 & 548.046 \\
\hline DACIEMERE & 5.14 & 135.696 & 20046 & 236.44 & 220.1976 \\
\hline
\end{tabular}

Figure 7 Calculated energy generation of the 4 case studies, according to NASA effective hours of annual solar radiation

Source: Own Elaboration

As a point of comparison and in order to obtain the efficiency of the system, the data from the monitoring of the modules in those months were also consulted, this being the real measure of the energy generated for each of the cases. The characteristics of the studied PV systems can be seen in Table 1: 


\begin{tabular}{|l|l|l|l|l|}
\hline \multicolumn{1}{|c}{ Case } & \multicolumn{1}{c}{$\mathbf{2}$} & \multicolumn{1}{c|}{$\mathbf{3}$} \\
\hline Inclination & $25^{\circ}$ & $30^{\circ}$ & $31^{\circ}$ & $31^{\circ}$ \\
\hline Orientation & $207^{\circ}$ & $168^{\circ}$ & $183^{\circ}$ & $161^{\circ}$ \\
& SOE & SE & SOE & SE \\
\hline SSFV capacity & 2.64 & 3.9 & 4.6 & 3.06 \\
& Kwh & Kwh & Kwh & Kwh \\
\hline Monitoring & Yes & Yes & No & Yes \\
\hline Interconnection & Central & Micro & Micro & Central \\
System & Inverter & Inverter & Inverter & Inverter \\
\hline
\end{tabular}

Table 1 Characteristics in the physical installation of the 4 PVSSs

Source: Own Elaboration

Figure 8 shows one of the systems studied.

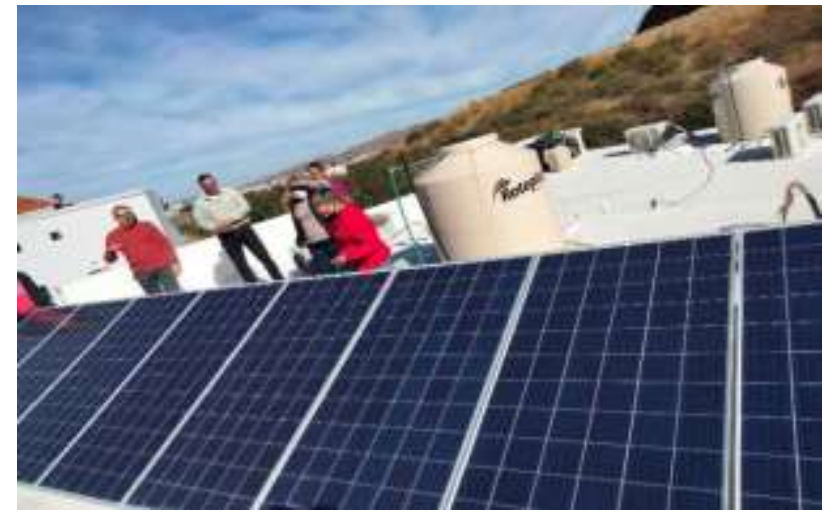

Figure 8 Physical installation of the FVSS, Case 1 Source: Own Elaboration

\section{Results}

\section{Study of the CFE bill}

There are very concrete learnings in this sense, since the meaning of the informative fields presented in the bill, as well as in the bidirectional meter and the monitoring system of the solar photovoltaic installation, were widely understood in each of the cases.

\section{Tour of the locations}

In this tour, the entire team attended the location of each installation. The inclination and orientation of the solar photovoltaic modules were observed, photographed and measured with an electronic device, in order to be able to compare each of the solar PV systems under study.

\section{Analysis of the CFE's monitoring and receipt system}

Due to the analysis performed, and after comparing the amount of energy generated, according to the monitoring system, and the CFE meter register in consumption and injection, it is understood and verified that in case 4, in spite of having high indexes in the generation of radiation of the $\mathrm{SSFV}$, which can be seen in Figure 9, it is not enough to achieve a balance between the household consumption, All this can be attributed to the lack of information and understanding of the information, both from the monitoring system and the CFE bill, and the household is advised to be more conscious in the use of energy or, if still necessary, to double its installation, and it could be an alternative to change to more efficient modules of $255 \mathrm{~W}$ to more than $410 \mathrm{~W}$.

In case 1, 2 and 3 very similar results are obtained, even though the inclination of the modules in case 1 are $5^{\circ}$ less than the others.

\begin{tabular}{|c|c|c|c|c|}
\hline \multirow{2}{*}{2021} & \multicolumn{4}{|c|}{ EFICIENCIA DE GENERACIÓN CON RADIACION } \\
\cline { 2 - 5 } & CASO 1 & CASO 2 & CASO 3 & CASO 4 \\
\cline { 2 - 5 } & EFICIENCIA & EFICIENCIA & EFICIENCIA & EFICIENCIA \\
\hline ENERO & $0 \%$ & $95 \%$ & $50 \%$ & $91 \%$ \\
\hline FEBRERO & $85 \%$ & $94 \%$ & $57 \%$ & $99 \%$ \\
\hline MARZO & $79 \%$ & $84 \%$ & $55 \%$ & $89 \%$ \\
\hline ABRIL & $79 \%$ & $71 \%$ & $63 \%$ & $84 \%$ \\
\hline MAYO & $85 \%$ & $78 \%$ & $52 \%$ & $87 \%$ \\
\hline JUNIO & $79 \%$ & $83 \%$ & $65 \%$ & $79 \%$ \\
\hline JULIO & $71 \%$ & $69 \%$ & $46 \%$ & $72 \%$ \\
\hline AGOSTO & $81 \%$ & $88 \%$ & $49 \%$ & $83 \%$ \\
\hline SEPTIEMBRE & $78 \%$ & $79 \%$ & $65 \%$ & $85 \%$ \\
\hline OCTUBRE & $78 \%$ & $85 \%$ & $58 \%$ & $91 \%$ \\
\hline NOVIEMBRE & $69 \%$ & $84 \%$ & $0 \%$ & $78 \%$ \\
\hline DICIEMBRE & $86 \%$ & $117 \%$ & $0 \%$ & $75 \%$ \\
\hline PROMEDIO & $79 \%$ & $86 \%$ & $47 \%$ & $84 \%$ \\
\hline
\end{tabular}

Figure 9 Generation efficiency in case studies Source: Own Elaboration

The following graph (Figure 10), presents a comparison between the four systems, in terms of efficiency, and a correct energy generation can be observed, with the exception of case 3 , where there is no monitoring and only the difference between both factors is recorded. 
Generation efficiency vs. calculated 2021

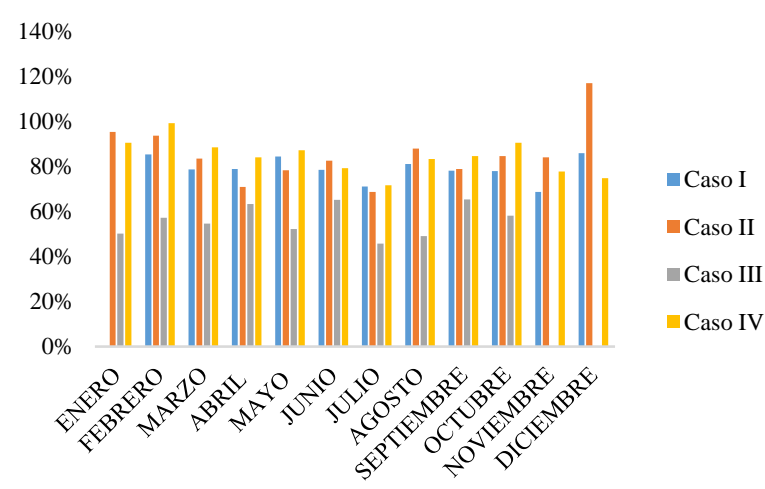

Figure 10 Generation efficiency vs. calculated 2021 Source: Own Elaboration

\section{Conclusions}

According to the results obtained from the analysis of the monitoring system data, as well as the CFE bill and the CFE bidirectional meter, the interconnected photovoltaic generator system in the city of Nogales, Sonora, is a good economic investment option to minimize and even eliminate the payment for energy to the CFE, As long as the same amount of energy analyzed for the installation continues to be consumed, as this can generate a false idea that it is possible to expand the energy demand, which will cause a higher consumption than what is generated by the system, making it necessary to expand the generation network or fall back into the DAC rate. Likewise, it is necessary to know and know how to interpret each of the sections of the CFE bill and the rules or statutes that regulate the use of SSFV.

Future work could include research on the CFE rules related to the use of SSFV, as well as providing advice and consultancy to consumers.

Through this analysis, the cost-benefit of the use of solar energy in the medium term is perceived, installing a PVSS for domestic use, even though it is considered a considerable investment for middle and lower middle class families, it is undoubtedly a profitable investment in many ways; firstly, in the expenditure per family of electric energy in the medium and long term;
On the other hand, the contribution in the conservation of the environment and the benefit for the country, since these systems contribute to the generation of energy for its use in different parts, reducing government investment and favoring the transition to less polluting energies, as indicated in the international agreements to which the country is a party.

\section{References}

Comisión Federal de Electricidad. (s.f.). Hogar. Obtenido de Tarifas: https://app.cfe.mx/Aplicaciones/CCFE/Tarifas/ TarifasCRECasa/Tarifas/Tarifa1A.aspx

García, E. (2004). Modificaciones al sistema de Clasificación Climática de Köppen. UNAM. Obtenido de: http://www.sema.gob.mx/SRN/SIIAEC/POETE /CUADROS/Cuadro_6_Descripcion_de_los_Ti pos_de_Climas.pdf.

National Aeronautics and Space Administration (2021). Prediction Of Worldwide Energy Resource. Recuperado de: https://power.larc.nasa.gov/data-access-viewer/ Tecnológico Nacional de México, U. T. (2020). Diagnóstico de las Tarifas Eléctricas en Nogales, Entorno Físico y Consumo. Nogales, Sonora.

Wheather, S. (2021). Datos históricos meteorológicos de 2021 en Nogales. Obtenido de:

https://es.weatherspark.com/h/y/2842/2021/Tie mpo-hist\%C3\%B3rico-durante-2021enNogales-M\%C3\%A9xico\#Figures-Temperature 